\title{
20: 6697207-6707769
}

National Cancer Institute

\section{Source}

National Cancer Institute. 20:6697207-6707769. NCI Thesaurus. Code C41790.

Physical location of BMP2_Gene 